\title{
HERMENEUTIKA FAZLUR RAHMAN: Upaya Membangun Harmoni Teologi, Etika, dan Hukum
}

\author{
Syamruddin \\ Fakultas Ushuluddin UIN Sultan Syarif Kasim \\ Jl. K.H. Ahmad Dahlan 94 Kecamatan Suka Jadi, Pekanbaru, 28129 \\ e-mail: mukhtarsyah@yahoo.co.id
}

\begin{abstract}
Abstrak: Tulisan ini mencoba mendiskusikan teori hermeneutika yang ditawarkan oleh Fazlur Rahman mencakup kritik Rahman terhadap teori sebelumnya, baik tradisional maupun kontemporer. Penulis menemukan bahwa Rahman menekankan pentingnya memahami al-Qur'an sebagai keseluruhan dan menjadi satu kesatuan yang utuh. Rahman juga membedakan antara hukum umum (prinsip) dan hukum temporal, dan menekankan pentingnya mempertimbangkan konteks untuk memahami al-Qur'an secara tepat. Penulis berargumen bahwa tujuan akhir teori Rahman adalah untuk membangun harmonisasi tiga aspek ajaran Islam dalam ranah hukum, etika dan hukum yang harus saling mendukung antara satu sama lain, yang didasarkan pada tiga prinsip dasar tatanan hubungan manusia yakni egalitarianisme, keadilan dan konsultasi mutual.
\end{abstract}

\begin{abstract}
Fazlur Rahman's Hermeneutics: An effort to Build Harmony Between Theology, Ethics and Law. This paper attempts to discuss the hermeneutical theory proposed by Fazlur Rahman. It includes therefore the discussion of Rahman's critique on the existing theories both traditional and contemporary ones. The author finds that Rahman emphasizes the importance of understanding al-Qur'an integrally as a single whole. He also distinguishes between general laws and temporary laws as well as stresses the importance of considering context to understanding al-Qur'an correctly. The author argues that the ultimate purpose of the theory is to build a harmony among three aspects of Islamic teaching: law, ethics, and theology, each of which has to support one another. In addition, there are three principles on which laws on human relation have to be built, namely egalitarianism, justice, and mutual consultation.
\end{abstract}

Kata Kunci: Al-Qur'an, hermeneutika, Fazlur Rahman, penafsiran

\section{Pendahuluan}

Ada tiga hal yang membedakan teori hermeneutika Fazlur Rahman dibandingkan dengan teori pemikir (scholars, 'ulamâ') lainnya. Pertama, perbedaan pendekatan dalam kajian. Konsep umum menggunakan pendekatan parsial/atomistik (juz $\hat{\imath}$ ), sementara Rahman 
menggunakan pendekatan holistik (kullî). Dengan kata lain, salah satu ciri hermeneutika Fazlur Rahman adalah pemahaman al-Qur'an secara keseluruhan (holistik). Rahman menyatakan, "satu bagian al-Qur'an menafsirkan bagian yang lain" atau "sekian bagian yang ada dalam al-Qur'an saling menafsirkan satu sama lain" (al-Qur'an yufassiru ba'dhuhu ba'dhan). ${ }^{1}$

Kedua, perbedaan penemuan Rahman dengan ulama lain dan merupakan kunci dasar hermeneutika Rahman adalah, beliau membedakan nash menjadi dua kelompok, yakni hukum umum di satu sisi dan hukum temporal di sisi lain. Sementara ulama pada umumnya tidak membedakan hal tersebut. Ketiga adalah penekanan Rahman tentang pentingnya memahami konteks untuk memahami al-Qur'an. Dalam satu kesempatan Rahman menjelaskan, "pada kenyataannya al-Qur'an adalah seperti ujung gunung es, di mana sembilan persepuluh yang terendam di bawah air dan hanya sepersepuluh yang terlihat." ${ }^{2}$

Rahman yang penekanannya pada pemahaman al-Qur'an secara holistik ( $k u l l i ̂)$ menempatkan teorinya sebagai pendekatan holistik (kullî). Demikian pula penekanan Rahman pada pentingnya memahami konteks untuk memahami al-Qur'an menempatkannya sebagai seorang kontekstualis. Tamara Sonn menyatakan, metode yang ditawarkan oleh Fazlur Rahman untuk mencapai pemahaman yang tepat dari prinsip Islam adalah salah satu kontribusi Rahman paling signifikan dan sangat mempengaruhi pemikiran dunia Islam. ${ }^{3}$

Tulisan ini mencoba menjelaskan teori hermeneutika Rahman. Setelah pendahuluan diikuti dengan deskripsi kritik Rahman terhadap teori sebelumnya, baik tradisional maupun kontemporer. Pada bagian berikutnya merupakan deskripsi tentang penekanan Rahman terhadap pentingnya memahami al-Qur'an sebagai keseluruhan dan menjadi satu kesatuan yang utuh, dan merupakan ciri pertama hermeneutika Rahman. Bahasan diikuti dengan penjelasan tentang pembedaan antara hukum umum (prinsip) dan hukum temporal. Bahasan kemudian dilanjutkan dengan karakter ketiga, pentingnya memahami konteks untuk memahami al-Qur'an.

\section{Kritik Rahman tentang Metode Tafsir}

Fazlur Rahman adalah seorang filosof Pakistan, pendidik dan pembaharu Islam terkemuka. Rahman lahir di Pakistan pada 1919, dan memperoleh gelar master dalam bahasa Arab dari Universitas Punjab, Lahore, pada tahun 1942, dan gelar doktor dalam Filsafat Islam dari Oxford University pada tahun 1949. Beliau juga menjadi Dosen di Studi Persia dan Filsafat Islam di Universitas Durham Institut Agama Islam 1958-1961, dan pernah berkunjung ke Pakistan sebagai profesor di Pusat Penelitian Institut Agama

${ }^{1}$ Fazlur Rahman, "Interpreting the Qur'an," dalam Afkar Inquiry: Magazine of Events and Ideas, May 1986, h. 45.

${ }^{2} I b i d$, h. 46.

${ }^{3}$ Tamara Sonn, "Fazlur Rahman's Islamic Methodology," dalam Muslim World, No. 81, No.34 (July-October, 1991), h. 213. 
Islam 1961-1962. Ia meninggalkan Pakistan karena kritik dan pemikirannya yang reformis, ia kemudian diangkat menjadi Visiting Profesor di University of California, Los Angles, pada musim semi 1969. Pada musim gugur dia pergi ke Universitas Chicago dan diangkat sebagai Profesor Pemikiran Islam. Meskipun awalnya Rahman mencapai ketenaran internasional di bidang filsafat, dengan publikasi Avicenna's Psychology (1952), Prophecy in Islam (1958) dan Avicenna's De Anima (1959), dia terkenal karena karya rintisannya di dalam hermeneutika Islam. Rahman meninggal dunia pada bulan Juli $1988 .{ }^{4}$

Fazlur Rahman yang tercatat sebagai sarjana pertama secara sistematis memperkenalkan penafsiran holistik, tidak secara eksplisit menyebut teorinya 'holistik'. Dalam satu kesempatan Rahman menyebutnya sebagai pendekatan sejarah, dan dalam artikel yang sama disebutkan pendekatan sosiologis. ${ }^{5}$ Sedangkan di kertas lain disebut sebagai teori hermeneutis. ${ }^{6}$ Bahkan Abdullah Saeed menyebut Rahman sebagai seorang kontekstualis. ${ }^{7}$

Untuk menempatkan konsep Fazlur Rahman dengan benar, adalah penting untuk memahami komentar dan kritik Rahman terhadap teori-teori sebelumnya. Rahman mengkritik metode penafsiran klasik dan pertengahan yang menggunakan pendekatan atomistik, yaitu memahami atau menafsirkan al-Qur'an ayat demi ayat. Terkait dengan kritiknya tersebut, Rahman menyatakan:

The classical and medieval commentators of the Qur'an have treated the Qur'an verse by verse; although sometimes they give cross-references to other verses of the Qur'an while commenting upon a verse, this has not been done systematically. The Qur'an commentaries therefore do not yield an effective 'weltanschauung' that is cohesive and meaningful for

${ }^{4}$ Tamara Sonn, "Fazlur Rahman" dalam The Oxford Encyclopedia of the Modern Islamic World, diedit oleh John L. Esposito (New York, Oxford: Oxford University Press, 1995) III: 408; Donald L. Berry, "Fazlur Rahman: A Life in Review," dalam The Shaping of An American Islamic Discourse, diedit oleh Earle H. Waugh and Frederick M. Denny (Atlanta and Georgia: Scholars Press, 1998), h. 37-48.

${ }^{5}$ Fazlur Rahman, "Islamic Modernism: Its Scope, Method and Alternatives," International Journal of Middle Eastern Studies, Vol. I (1970), h. 329-330. Dalam bahasa Rahman, "a sober and honest historical approach must be used for finding the meaning of the Qur'anic text. The metaphysical aspect of Qur'anic teaching may not lend itself very easily to historical treatment, but the sociological part certainly will". Ibid., h. 329; "difficulties and difference of interpretation will undoubtedly also on this sociological approach, but it is the only approach that can also lead to satisfactory solutions". Ibid., h. 330.

${ }^{6}$ Fazlur Rahman, "Interpreting the Qur'an," h. 45. Dalam bahasa Rahman, "Nevertheless there is a dire need for a hermeneutical theory that will help us understand the meaning of the Qur'an as a whole so that both the theological section of the Qur'an and its ethical and ethicolegal parts become a unified whole". Ibid.; Selanjutnya dikatakan, "But the method of Qur'anic hermeneutics I am talking about is concerned with an understanding of its message that will enable those who have faith in it and want to live by its guidance - in both their individual and collective lives - to do so coherently and meaningfully". Fazlur Rahman, Islam and Modernity: Transformation of an Intellectual Tradition (Chicago \& London: The University of Chicago Press, 1982), h. 4.

${ }^{7}$ Abdullaah Saeed, Interpreting the Qur'an: Towards a Contemporary Approach (London \& New York: Routledge, 2006), h. 3, 6, 128. 
life as a whole". ${ }^{8}$ Artinya, para penafsir klasik dan pertengahan menafsirkan al-Qur'an ayat demi ayat. Walaupun kadang-kadang mufasir menghubungkan pembahasan dengan ayat lain, namun dilakukan bukan secara sistematis. Akibatnya, tafsiran al-Qur'an tidak menghasilkan 'weltanschauung' yang efektif, kohesif dan bermakna bagi kehidupan dalam segala aspek.

Di tempat lain Rahman menulis, "there was a general failure to understand the underlying unity of the Qur'an, coupled with a practical insistence upon fixing on the words of various verses in isolation. The result of this "atomistic" approach was that laws were often derived from verses that were not at all legal in intent". ${ }^{9}$ Artinya, "ada kegagalan umum dalam memahami kesatuan al-Qur'an, ditambah dengan desakan praktis memahami ayat al-Qur'an secara terpisah. Hasil pendekatan 'atomistik' ini sering mengambil dan menetapkan hukum dari ayat-ayat yang sebenarnya bukan bermuatan hukum". Menurut Rahman, al-Qur'an sendiri menegaskan secara jelas bahwa al-Qur'an adalah sumber ajaran yang sangat terintegrasi dan kohesif:

The contention that certainty belongs not to the meanings of particular verses of the Qur'an and their content but to the Qur'an as a whole, that is, as a set of coherent principles or values where the total teaching will converge, might appear shocking to many Muslims who have been for centuries habituated to think of the laws of the Qur'an in a discrete, atomistic, and totally unintegrated manner (even though the Qur'an loudly proclaims that it is a highly integrated and cohesive body of teaching). ${ }^{10}$ Artinya, bahwa kepastian bukan dari ayat-ayat tertentu dari al-Qur'an melainkan isi al-Qur'an secara keseluruhan. Prinsip atau nilai koheren ini mungkin mengejutkan banyak muslim karena telah berabad-abad terbiasa memahami al-Qur'an secara terpisah-pisah (atomistik), dan benar-benar tidak terintegrasi, meskipun al-Qur'an tegas menyatakan bahwa alQur'an adalah sumber ajaran yang sangat terintegrasi dan kohesif.

Salah satu contoh akibat negatif dari penggunaan pendekatan atomistik, pada saat yang sama menunjukkan pentingnya pemahaman yang koheren, adalah dalam hukum pembunuhan. Al-Qur'an memberikan dua kemungkinan hukuman bagi pembunuh, yakni membayar diyat atau dibunuh (qishas), dengan menambahkan bahwa memberikan ampunan lebih baik. Menurut Rahman, semua ahli hukum menyimpulkan bahwa pembunuhan masuk ke dalam kejahatan pribadi, yang karenanya hukumannya tergantung pada keluarga yang ditinggalkan, apakah pembunuh akan diampuni, membayar diyat, atau dihukum bunuh. Padahal al-Qur'an menetapkan prinsip yang lebih umum bahwa, 'seseorang yang membunuh orang lain di bumi tanpa alasan atau bukan masa perang, seakan ia telah membunuh semua umat manusia' (sebagaimana disebutkan dalam Q.S. al-Mâ' idah/5:

${ }^{8}$ Rahman, "Interpreting the Qur'an," h. 45.

${ }^{9}$ Rahman, Islam and Modernity, h. 2-3.

${ }^{10}$ Ibid., h. 20. 
32). Dari hal ini jelas bahwa pembunuhan lebih merupakan kejahatan (pidana) umum ketimbang pidana pribadi. ${ }^{11}$ Sebaliknya, pidana pencurian adalah kejahatan pribadi. ${ }^{12}$

Kritik lain dari Rahman terhadap pendekatan klasik dan pertengahan dalam studi Islam adalah kurang atau tidak memperhatikan konteks dan sejarah al-Qur'an, hanya berkonsentrasi pada teks al-Qur'an. Secara keseluruhan, Rahman menyebutkan bahwa ada tiga kelemahan pendekatan klasik dan pertengahan, yaitu: (1) Perhatian yang tidak cukup terhadap latar belakang historis pewahyuan al-Qur'an, (2) Berkonsentrasi pada teks al-Qur'an, dan (3) Atomistik dalam memahami al-Qur'an.

Rahman setuju dengan pentingnya memahami bahasa; gaya, idiom, dan kiasan, seperti yang ditekankan ulama Klasik dan Pertengahan (bahkan beberapa pemikir kontemporer). Namun kepentingan analisis bahasa ini hanya untuk memahami teks al-Qur'an. Dalam ungkapan Rahman, "bahasa penting untuk memahami teks al-Qur'an, namun ada kebutuhan mendesak terhadap hermeneutis yang akan membantu kita memahami al-Qur'an sebagai keseluruhan, sehingga bagian teologis al-Qur'an, bagian etika, dan bagian hukum, menjadi satu kesatuan yang utuh". ${ }^{13}$

Rahman juga menyatakan, "Jika kita perhatikan, al-Qur’an tidak memberikan banyak prinsip umum. Sebagian besar isi al-Qur'an memberikan solusi atau keputusan atau hukum terhadap masalah konkret yang muncul ketika itu. Tetapi seperti telah saya katakan, jawaban-jawaban terhadap kasus-kasus konkret tersebut menyediakan alasan-alasan, baik secara eksplisit ataupun implisit. Alasan-alasan di balik solusi atau keputusan atau hukum tersebut dapat disimpulkan dan dirumuskan menjadi prinsip-prinsip umum". ${ }^{14}$ Dalam setidaknya tiga dari tulisan-tulisannya, ${ }^{15}$ Rahman menekankan tiga unsur dalam pendekatannya, yaitu: konteks ayat-ayat (konteks teks), susunan gramatikal teks, dan menjadikan semua teks al-Qur'an sebagai satu kesatuan yang utuh sebagai 'weltanschauung'.

Kritik lain dari Rahman terhadap metode klasik adalah penggunaan qiyas, istiḩsân, mashlahah mursalah, dharûrat, nâsikh-mansûkh, marhalîyah, serta '̂̂mm dan khashsh. Kritiknya terhadap qiyas, istiḩsân, mashlahah mursalah, dan dharûrat adalah standar penggunaan yang subjektif. Kadang menggunakan standar sempit dan dangkal sedangkan pada saat lain menggunakan standar mendalam. Adapun terhadap konsep pembatalan (nâsikhmansûkh), Rahman melihat lebih sebagai dasar keyakinan bahwa konteks yang berbeda menghasilkan hukum yang berbeda, bukan ada ayat yang membatalkan ayat lain. Sedangkan

${ }^{11}$ Ibid., h. 144; Rahman., h. 46.

${ }^{12}$ Rahman, "Interpreting the Qur'an," h. 46.

${ }^{13}$ Ibid., h. 45.

${ }^{14}$ Rahman, Islam and Moderntiy, h. 20.

${ }^{15}$ Rahman, Major Themes of the Qur'an (Chicago: Bibliothca Islamica, 1980); Rahman., "Some Key Ethical Concepts of the Qur'an," dalam Journal of Religious Ethics, Vol. XI, No. 2 (1983), h. 170-185; Rahman., "The Qur'anic Concept of God, the Universe and Man," dalam Islamic Studies, Vol. VI, No. 1 (1967), h. 1-19. 
konsep 'âmm dan khashsh menurut Rahman bahwa aturan umum ('âmm) menjadi lebih mendasar, dan karenanya putusan-putusan spesifik (khashsh dimasukkan di bawah ketentuan umum. ${ }^{16}$ Oleh karena itu, Rahman memegang teori al-'ibratu bi 'umûm al-lafzh lâ bi khushûsh al-sabab bukan al-'ibratu bi khushûsh al-sabab lâ bi 'umûm al-lafzh.

Berkenaan dengan teori hermeneutik, Rahman menawarkan dua langkah utama dalam menerapkan metodenya, yang terkenal disebut 'gerakan ganda'. Langkah pertama adalah bergerak dari kasus konkret/khusus/spesifik/temporal ${ }^{17}$, yang ditetapkan al-Qur'an untuk menemukan prinsip umum. Sementara langkah kedua adalah bergerak dari prinsip umum kembali ke kasus khusus. Baik untuk menemukan prinsip-prinsip umum dari jawaban spesifik al-Qur'an maupun ketika menggunakan prinsip-prinsip umum untuk menjawab atau menyelesaikan kasus-kasus khusus, adalah perlu memperhitungkan kondisi sosial yang relevan (konteks). Rahman menulis:

Dalam membangun atau menetapkan hukum dan institusi Islam sejati dan layak, harus ada gerakan ganda: Pertama, kita harus bergerak dari kasus konkret yang diselesaikan alQur'an dengan mempertimbangkan kondisi sosial yang relevan pada waktu itu, untuk menetapkan prinsip-prinsip umum yang di atasnya seluruh ajaran menyatu. Kedua, dari prinsip umum tersebut harus ada gerakan kembali ke legislasi khusus masa sekarang, juga dengan mempertimbangkan kondisi sosial yang diperlukan dan relevan dengan kondisi dan tuntutan sekarang. ${ }^{18}$

Gerakan pertama dari dua gerakan tersebut terdiri dari dua langkah. Langkah pertama adalah memahami makna pernyataan yang diberikan dengan cara memahami situasi historis dari masalah, yang terhadap masalah tersebut jawaban diberikan. Langkah kedua adalah menggeneralisasi jawaban-jawaban spesifik tersebut dan menempatkannya sebagai tujuan umum yang bersifat sosial-moral. ${ }^{19}$ Rahman mengatakan tentang pentingnya teori hermeneutis, "ada kebutuhan mendesak terhadap teori hermeneutik yang akan membantu kita memahami al-Qur'an sebagai keseluruhan, sehingga bagian teologis al-Qur'an, etika alQur'an, dan hukum al-Qur'an, menjadi satu kesatuan yang utuh". ${ }^{20}$

Karakteristik teori hermeneutik Rahman, oleh karena itu, ada tiga. Pertama, penekanannya pada kebutuhan untuk memahami al-Qur'an dalam kesatuan secara keseluruhan (satu kesatuan). Kedua, membedakan antara hukum umum dan hukum khusus (hukum temporal), yang di banyak tempat disebut etis dan ethico-hukum. Ketiga, pentingnya pemahaman latar belakang dan konteks historis untuk memahami al-Qur'an. Bagian berikut merupakan

\footnotetext{
${ }^{16}$ Rahman, "Interpreting the Qur'an," h. 49.

${ }^{17}$ Empat istilah untuk menunjukkan maksud sama, yakni hukum konkret, hukum khusus, hukum spesifik, hukum temporal. Semua dimaksudkan untuk menunjukkan subjek sama, sebagai lawan dari hukum umum (prinsip).

${ }^{18}$ Rahman, Islam and Modernity, h. 20.

${ }^{19}$ Ibid., h. 6.

${ }^{20}$ Rahman, "Interpreting the Qur'an", h. 45.
} 
penjelasan tentang gerakan ganda hermeneutika Rahman; bagaimana kaitannya dengan pemahaman al-Qur'an sebagai satu kesatuan, membedakan antara hukum umum dan hukum khusus atau hukum temporal, dan hubungannya dengan pentingnya pemahaman konteks untuk memahami al-Qur'an.

\section{Memahami al-Qur'an sebagai Satu Kesatuan}

Label yang sama untuk sebutan memahami al-Qur'an sebagai satu kesatuan (pendekatan holistik) adalah induktif dan integratif (al-istiqrẩi). Rahman tidak menyebut teorinya dengan pendekatan 'holistik', melainkan ia menyebutnya teori hermeneutis, ${ }^{21}$ bahkan sebelumnya disebut teori atau pendekatan historis, atau pendekatan sosiologis. ${ }^{22}$ Rahman misalnya menyatakan, "ada kebutuhan mendesak terhadap teori hermeneutik yang akan membantu kita memahami makna al-Qur'an secara keseluruhan, sehingga aspek teologis al-Qur'an, aspek etika, dan aspek hukum menjadi satu kesatuan yang utuh". ${ }^{23}$

Pendekatan holistik yang diajukan Rahman berbeda dengan pendekatan tematik yang diusulkan oleh beberapa sarjana, seperti Amin al-Khuli, al-Farmawî, Bint al-Syâthi', Shahrûr, Nashr Hamid Abû Zayd dan lain-lain. Namun, baik pendekatan tematik maupun holistik sama-sama menekankan perlunya pendekatan induktif atau lintas referensial (al-manhaj al-istiqrâii), ${ }^{24}$ yakni menghubungkan seluruh ayat yang membahas masalah atau subjek yang sama.

Al-Ghazâlî (w. 505/1111) adalah sarjana pertama yang memperkenalkan pendekatan induktif dalam bukunya al-Mustashfâ min ilm al-Ushûl. Sarjana lain yang memperkenalkan pendekatan serupa adalah al-Syâthibî (w. 790/1388), yang menawarkan pendekatan integral, dan menyatakan bahwa "satu bagian al-Qur'an menafsirkan yang lain" atau "bagian-bagian yang berbeda dalam al-Qur'an menjelaskan satu sama lain" (al-Qur 'ân yufassiru ba'duhu ba'dhan), sebuah prinsip yang sudah ada sejak zaman sahabat. Al-Syâthibî, seorang ulama terkenal dari mazhab Mâliki, dalam bukunya Al-Muwâfaqât, mengulangi tentang pentingnya pendekatan induktif dalam tafsir. Bagi Al-Syâthibî penggunaan pendekatan induktif ini merupakan bagian dari konsep bahwa kalam Allah merupakan kalam satu kesatuan (kalâmun ilâhiyun huwa kalâmun wâhidun). ${ }^{25}$

${ }^{21}$ Fazlur Rahman, "Approaches to Islam in Religious Studies: Review Essay" dalam Approaches to Islam in Religious Studies, diedit oleh Richard C. Martin (Tucson: The University of Arizona Press, 1985), h. 198; Idem., Islam and Modernity, h. 5.

${ }^{22}$ Rahman, "Islamic Modernism," h. 330. Tamara Sonn meletakkan teori Fazlur Rahman sebagai 'historicism,' sama dengan Mohamad Arkoun (seorang sarjana dari Algeria) dan 'Abdullah alNaim (seorang sarjana dari Tunisia). Sonn, "Fazlur Rahman's, h. 227.

${ }^{23}$ Rahman, "Interpreting the Qur'an", h. 45.

${ }^{24}$ Sahiron Syamsuddin, "An Examination of Bint Bint al-Syâthi"s Method of Interpreting the Qur'an" (Montreal: MA. Thesis, McGill University, 1998), h. 20, 44.

${ }^{25}$ Ibrâhîm ibn Mûsâ al-Syâthibî, al-Muwâfaqât, diedit oleh Muhammad Muhy al-Dîn 'Abd al-Hâmid (Kairo: Maktabat wa Mathba'at Muhammad 'Alî Shâbih wa Awlâdih, 1969), h. 284. 
Demikian juga pendekatan induktif ini diletakkan oleh Ibn Taimîyah (d.728/1328) dan al-Zarkashî sebagai metode terbaik dalam menafsirkan al-Qur'an. ${ }^{26}$ Namun demikian, penerapan pendekatan induktif ini belum ditemukan dalam kitab 'ulamâ' (sarjana) brilian ini. Rahman, oleh karena itu, mencoba merumuskan metode tersebut secara sistematis dan menerapkannya dalam menanggapi isu-isu kontemporer. Rahman menyatakan bahwa seluruh elemen teorinya telah ada sejak zaman sahabat, bahkan sejak Nabi Muhammad SAW. Apa yang baru dari Rahman adalah merumuskannya untuk menjadi suatu metode sistematis. Dalam ungkapan Rahman, pendekatan yang dianjurkan di sini adalah baru meskipun, seperti yang saya katakan sebelumnya, seluruh materinya sudah ada sejak lama. Unsur baru dari yang ditawarkan hanya terdiri dari konsep, mempelajari al-Qur'an secara keseluruhan (total) dan spesifik, dan melakukannya secara sistematis sesuai dengan urutan sejarah (kronologi), bukan menafsirkan ayat demi ayat atau surah demi surah dengan memisahkannya (terisolasi) dari latar belakang (historical background/sha'n al-nuzûl). ${ }^{27}$

Rahman menekankan pentingnya memahami al-Qur'an sebagai satu kesatuan. Beberapa kutipan tentang masalah ini telah disebutkan sebelumnya dalam hubungannya dengan kritik terhadap metode klasik dan modern. Pada saat yang sama Rahman mengusulkan pendekatan holistik, dan bahkan berpendapat bahwa al-Qur'an itu sendiri tegas menyatakan bahwa al-Qur'an merupakan sumber ajaran yang terintegrasi dan kohesif. ${ }^{28}$ Demikian juga al-Qur'an harus dipahami dengan latar belakang historisnya. Dengan kata Rahman, "bagian dari tugas memahami pesan al-Qur'an sebagai satu kesatuan adalah mempelajarinya lengkap dengan latar belakangnya. Latar belakang langsung adalah kegiatan Nabi Muhammad sendiri dan perjuangannya yang berlangsung selama sekitar dua puluh tiga tahun di bawah bimbingan dari al-Qur'an". ${ }^{29}$ Karena itu jelas bahwa selain menekankan pentingnya memahami al-Qur'an secara keseluruhan sebagai satu kesatuan. Rahman menekankan pentingnya memahami latar belakang dan konteks untuk memahami al-Qur'an.

Memahami al-Qur'an sebagai satu kesatuan dan menyatukan aspek teologi, etika, dan hukum, muncul ketika Rahman mengkritik modernis dengan mengatakan, "modernis hanya sedikit berusaha memperlakukan al-Qur'an sebagai satu kesatuan dan merumuskan pandangan dunia sebagai langkah pertama, kemudian menyusun etika dan akhirnya menetapkan hukum dan/atau aturan dan/atau undang-undang". ${ }^{30}$ Rahman, oleh karena itu, ingin menghubungkan dan membuat satu kesatuan dari tiga aspek yang tidak terpisahkan dari ajaran Islam, yang merupakan hasil dialog antara Nabi Muhammad dan

${ }^{26}$ Taqi al-Dîn Ibn Taimîyah, Muqaddimah fî Ushûl al-Tafsîr (Beirût: Dâr Ibn Hazm, 1994), h. 93; dan Muhammad ibn 'Abdillâh al-Zarkashî, al-Burhân fì 'Ulûm al-Qur'ân, diedit oleh Muhammad Abû al-Fadhl Ibrâhîm (Kairo: Dâr Ihyâ al-Kutub al-Arabîya, 1957), h. 175.

${ }^{27}$ Rahman, Islam and Modernity, h. 145.

${ }^{28}$ Ibid., h. 20.

${ }^{29}$ Rahman, "Interpreting the Qur'an", h. 45.

${ }^{30}$ Fazlur Rahman, "Islam: Legacy and Contemporary Challenge", dalam Islamic Studies, 19, 4 (1980), h. 244. 
Jibrîl, yaitu iman (teologi, dalam arti pandangan dunia), Islam (undang-undang dan/ atau hukum dan/atau aturan), dan ihsan (etika). Rahman berupaya untuk membangun hubungan harmoni dan koheren antara tiga aspek dari ajaran Islam tersebut. Berdasarkan teori ini, etika berasal dari undang-undang dan/atau hukum dan/atau aturan sebagai hasil dari generalisasi. Generalisasi, yang berarti dari khusus ke umum ini merupakan langkah pertama dari teori hermeneutika Rahman. Selain itu, etika ini juga disebut sebagai tujuan, objektif, dan nilai dari undang-undang dan/atau hukum dan/atau aturan.

Etika bagi Rahman merupakan nilai tertinggi dari prinsip umum, dasar al-Qur’an. Sebelum sampai pada level tertinggi ini, dimulai dari prinsip yang lebih rendah, dengan cara melakukan generalisasi dari atau berdasarkan pada sejumlah undang-undang dan/ atau hukum dan/atau aturan dalam al-Qur'an. Misalnya, kesetaraan dan keadilan merupakan prinsip tertinggi dalam hubungan manusia. Prinsip ini merupakan hasil generalisasi dari beberapa prinsip yang lebih rendah yang ada di bawahnya, yang mengatur hubungan antara manusia, yang ditemukan dengan melakukan generalisasi terhadap undangundang dan/atau hukum dan/atau aturan yang lebih rendah, yang mengatur hubungan antara manusia. Akhirnya, prinsip terendah ditemukan berupa prinsip hubungan antara suami dan istri, juga dengan cara melakukan generalisasi dari undang-undang dan/ atau hukum dan/atau aturan khusus yang mengatur hubungan suami dan istri.

Prinsip hubungan antara suami dan istri ini juga merupakan hasil generalisasi dari sejumlah undang-undang dan/atau hukum dan/atau aturan antara suami dan istri. Undangundang dan/atau hukum dan/atau aturan dimaksud adalah hukum yang diberikan alQur'an tentang hak dan tanggung jawab antara suami dan istri, tentang status poligami, status mahar, dan lain-lain dalam kehidupan rumah tangga. Dengan kata lain, apa yang disebut prinsip terdiri dari berbagai tingkatan. Maka prinsip yang paling tinggi itulah yang disebut etika. Etika sebagai prinsip tertinggi dinyatakan Rahman ketika mengkritik penggunaan qiyas, istihssan, mashlahah mursalah, dharuri, âmmm dan khâshsh. Dalam ungkapan Rahman:

Dalam rangka memperbaiki sempitnya qiyas, para ulama merumuskan prinsip-prinsip lain di luar qiyas berupa mashlahah dan istihssan yang umumnya berarti keadilan hukum dan kepentingan orang banyak (publik). Mereka misalnya mendefinisikan istiḩsan, sebagai prinsip yang lebih tinggi dari qiyas yang akan digunakan dalam kasus di mana qiyas tidak dapat menyelesaikan. Mashlahahah didefinisikan sebagai kepentingan umum. Demikian pula, konsep darurat disusun untuk menciptakan fasilitas bagi kewenangan pemerintah untuk melaksanakan tugas-tugas yang dipandang perlu demi kepentingan masyarakat (orang banyak atau publik). Jika fukaha telah menetapkan prinsip secara sistematis dengan menggali illat hukum dari al-Qur'an dan prinsip-prinsip tersebut telah disusun secara hierarki dari yang lebih umum kepada yang lebih spesifik, dari yang lebih mendasar ke kurang mendasar. Maka mereka mestinya bisa menempatkan prinsip-prinsip yang lebih rendah di bawah prinsip-prinsip yang lebih tinggi. Sayang, apa yang dilakukan bukannya melakukan kegiatan yang sistematis seperti itu, mereka malah menetapkan prinsip keadilan (istihssan), prinsip kepentingan umum (mashlahah 
mursalah) dan prinsip kebutuhan (dharurat), yang menurut sifatnya prinsip-prinsip tersebut tidak mesti sejalan dengan prinsip-prinsip yang ditetapkan dalam al-Qur'an atau sunah nabi. Karena itu hasilnya malah saya takut melahirkan kekacauan. ${ }^{31}$

Berdasarkan berbagai tingkatan prinsip dan contoh-contoh yang dikutip Rahman, pemahaman al-Qur'an sebagai keseluruhan dan satu kesatuan, dimulai dengan memahami satu subjek atau tema tertentu. Hasil penggunaan pendekatan tematik dalam memahami subjek tertentu tersebut kemudian digunakan untuk memahami subjek lain dengan metode serupa. Akhirnya, semua subjek dalam al-Qur'an; teologi, etika dan hukum, dibangun menjadi satu sebagai keseluruhan dan kesatuan. Karena itu ada hubungan dan kesamaan antara pendekatan tematik dan holistik, meskipun ada perbedaan, yang dapat diketahui persamaan dan perbedaannya lebih jelas dengan menggambarkan penerapan pendekatan tematik berikut.

Amin al-Khûllî (1895-1966), yang secara umum diakui sebagai sarjana Muslim pertama pada abad kedua puluh yang menekankan pentingnya pendekatan tematik dalam memahami al-Qur'an, tidak menulis definisi pendekatan ini. Dia memang menekankan pentingnya memahami dua sisi dari al-Qur'an dalam rangka memahami al-Qur'an secara sempurna, yakni: arti (ma'na) dan tujuan (aghrâd) ayat-ayat al-Qư'an. ${ }^{32}$ Al-Khûllî bersikeras bahwa ada dua bidang utama pengetahuan (dirâsât) yang dibutuhkan agar memungkinkan pemahaman yang tepat terhadap al-Qur'an, yaitu: (1) Pemahaman al-Qur'an sendiri (dirâsâtfĩ al-Qurân), dan (2) Pemahaman konteks atau latar belakang al-Qur'an (dirâsât mâ haul al-Qur'an). Wilayah pertama meliputi kata-kata (mufradât) al-Qur'an dan struktur (murakkabât) bahasa al-Qur'an, ${ }^{33}$ sedangkan pengetahuan tentang konteks atau latar belakang al-Qur'an terdiri dari segala sesuatu yang berkaitan dengan kehidupan awal Arab (al-bî’ah al-mâdîah), dan bî’ah al-ma'nawîyah Arab, di mana situasi al-Qur'an diturunkan. ${ }^{34}$ Jadi, sosiologi masyarakat Muslim asli sangat penting untuk memahami latar belakang Kitab Suci (haul al-Qur'an). ${ }^{35}$

Penerapan pendekatan tematik, menurut al-Khûllî, melibatkan pertama: (1) Mengambil kasus/subjek tertentu (maudhû' al-wâhid), kemudian (2) Menemukan seluruh ayat yang berbicara subjek tersebut dalam seluruh al-Qur'an dari awal sampai akhir, dan terakhir (3) Memahami hubungan antara ayat-ayat (sâbiqihâ wa lâhiqihâ) ketika membahas subjek. Karena itu, al-Khûllî menekankan pentingnya pemahaman mulâbisât, munâbisât, dan asbâb al-nuzûl, ${ }^{36}$ sebelum membahas masalah secara tematis atau kasus per kasus. ${ }^{37}$

\footnotetext{
${ }^{31}$ Rahman, "Interpreting the Qur'an", h. 48.

${ }^{32}$ Amîn al-Khûlî, Manâhij Tajdîd fí al-Nahw wa al-Balâghah wa al-Tafsîr wa al-Adab (t.t.p.: Al-Hai'ah al-Mishriyah al-'Âmmah li al-Kitâb, 1995), h. 232.

${ }^{33}$ Ibid., h. 238.

${ }^{34}$ Ibid., h. 235.

${ }^{35}$ Ibid., h. 240.

${ }^{36} I b i d .$, h. 232.

${ }^{37}$ Ibid., h. 233.
} 
Singkatnya, prosedurnya adalah sebagai berikut: (1) Mengumpulkan ayat tentang topik bahasan, kemudian (2) Menghubungkan semua ayat sebagai suatu kesatuan, dan (3) Mengatur hubungan ayat sesuai dengan implikasi dari topik.

Binti al-Shâthi', murid (dan kemudian istri) al-Khûlî, yang juga menyukai pendekatan tematik (maudhû' al-wâhid), juga tidak memberikan definisi metode ini. Untuk memahami posisi dia, perlu memahami responsnya terhadap metode tafsir klasik pertengahan (salaf), yakni empat hal: (1) Di dalamnya masuk unsur-unsur asing, seperti Israilîyat (Yahudi-Kristen), (2) Menampilkan kecenderungan sektarian atau tendensius (al-ta'milât al-'ashâbiya); (3) Memaksakan penafsiran; (4) Tidak memahami kekhasan retorika al-Qur'an dan sering mengabaikan keajaibannya (i'jâzz al-Qur'an). ${ }^{38}$

Sebagai gantinya, Binti al-Shâthi' menawarkan metode interkonektif (cross referensial), seperti metode yang ditawarkan guru dan suaminya, al-Khûlî. Tetapi dia membuat tiga poin dalam teoretis. Pertama, menekankan pentingnya arti leksikal dari setiap kata al-Qur'an. Pengakuan terhadap arti asli dari sebuah kata, tentu saja, dapat membantu penafsir memahami makna (al-mána al-murâd) dalam konteks teks. Kedua, menekankan pada keterlibatan dan keterikatan seluruh ayat-ayat al-Qur'an yang berkaitan dengan topik yang dibahas. Dengan prinsip ini berarti al-Qur'an diberikan kewenangan untuk berbicara tentang al-Qur'an sendiri dan oleh al-Qur'an sendiri, yang dengan metode itu dapat menghasilkan penafsiran yang objektif. Ketiga, dalam upaya memahami kata-kata dan konsep al-Qur'an, perlu ada kesadaran tentang konteks tekstual khusus (al-siyâq al-khâshsh) dan konteks tekstual umum (al-siyâq al-'âmm). ${ }^{39}$

Binti al-Shâthi' juga mengkritik penggunaan tafsir surah demi surah yang banyak digunakan penafsir kontemporer. Tawaran yang diberikan lagi-lagi tafsir interkonektif. Karena itu, di samping mengkritik mufasir Klasik dan Pertengahan, Binti al-Shâthi' juga menolak pendekatan tafsir surah demi surah yang banyak digunakan ilmuwan kontemporer. Sebaliknya, dia menyarankan pendekatan tematik. Dalam tafsir yang ditawarkan, di samping Binti al-Shâthi` berkonsentrasi pada kata-kata, kalimat dan struktur al-Qur'an, juga berusaha menanggalkan pemahaman yang bersumber dari luar al-Qur'an. Penjelasan al-Qur'an harus didasarkan pada teks al-Qur'an itu sendiri, berdasarkan bacaan dalam teks, bukan tanpa dan/atau di luar teks al-Qur'an. Baginya di antara masalah interpretasi adalah memurnikan dari gagasan non Islam dan/atau non Qur'ani. Dia memberikan kritik keras terhadap penafsiran yang bersifat mistis dan filosofis, yang menurut dia sebagian besar didasarkan pada ajaran-ajaran di luar al-Qur'an. Hal penting lain yang ditekankan oleh Binti al-Shâthi' adalah perlunya pemahaman konteks dalam memahami teks al-Qur'an. Baginya, untuk memahami teks al-Qur'an dengan benar membutuhkan pemahaman konteks, baik mikro maupun makro.

\footnotetext{
${ }^{38}$ Binti al-Shâthi', al-Qur 'an wa Tafsîr 'Ashr (Kairo: Dâr al-Ma'ârif, 1970), h. 24-32; Syamsuddin Sahiron, An Examination of Binti al-Shâthi's Method, h. 10.

${ }^{39}$ Binti al-Shâthi', al-Tafsîr al-Bayânî, I: 10, dan II:7, Sahiron, An Examination of Binti alShâthi"s Method, h. 48.
} 
Al-Farmâwî, penafsir lain yang juga dipengaruhi al-Khûlî, adalah sarjana pertama yang mencoba mendefinisikan dan merumuskan metodologi tematik secara sistematis, baik tematik berdasarkan subjek maupun tematik berdasarkan surah dari al-Qur'an. Tematik berdasarkan surah dilakukan dengan berkonsentrasi atau menekankan pada surah tertentu dari al-Qur'an. Idenya adalah bahwa setiap surah mempunyai penekanan pada subjek tertentu meskipun di dalamnya membahas topik berbeda-beda, dan semua ayat dalam surah tersebut berkaitan dengan subjek utama. Demikian pula, ayat lain yang terkait dengan topik utama dari surah-surah lain, juga harus disertakan dalam pembahasan, yang tujuannya adalah untuk menemukan koheren dengan tema bahasan. Karena itu, ayat dalam surah dan ayat-ayat terkait lainnya dari surah-surah lain digunakan dan dibahas secara koheren.

Sementara tematik berdasarkan subjek dapat dilakukan dengan mengumpulkan semua ayat yang relevan dengan subjek bahasan dari awal sampai akhir al-Qur'an, dan kemudian memahaminya secara kronologis, sehingga ditemukan pemahaman yang komprehensif terhadap topik bahasan. Singkatnya, tafsir tematik dapat dikelompokkan menjadi dua, yakni berdasarkan surah demi surah dari al-Qur'an, dan subjek atau masalah tertentu. ${ }^{40}$

Berdasarkan definisi tersebut, ada beberapa langkah yang harus diikuti dalam menggunakan pendekatan tematik berdasarkan subjek. Pertama, mengumpulkan seluruh ayatayat yang terkait dengan topik atau subyek bahasan. Kedua, menghubungkan seluruh ayat secara bersama-sama, koheren, dan tidak terpisah. Dalam membuat hubungan harus diletakkan ayat-ayat dalam urutan kronologis berdasarkan urutan wahyu. Langkah terakhir, semua ayat harus dipahami lengkap dengan memahami konteks (asbâb al-nuzûl), serta dalam sinaran tradisi Nabi (Sunnah). ${ }^{41}$

Apa yang dapat disimpulkan dengan membandingkan antara pendekatan tematik dan holistik. Pertama, keduanya sama-sama menyadari pentingnya pemahaman terhadap konteks historis, dan mengklasifikasikan konteks tersebut menjadi dua jenis. Pertama, peristiwa penyebab turunnya wahyu (asbâb al-nuzûl) sebagai konteks mikro (microsituation). Kedua, sosio-historis Arab sebagai konteks makro (macrosituation). Namun demikian, Rahman lebih menekankan pentingnya makro dibandingkan dengan al-Khûllî.

Kedua, baik pendekatan tematik mapun holistik sama-sama menekankan perlunya pendekatan lintas-referensial atau induktif. Ini berarti semua ayat al-Qur'an dan Sunnah Nabi Muhammad yang membahas topik bahasan sama, harus dipahami secara induktif, integratif, dan berkorelasi secara keseluruhan dan kesatupaduan.

Perbedaan dasar antara pendekatan tematik berdasarkan subjek, dan pendekatan holistik, seperti yang telah disebutkan sebelumnya, bahwa dalam tematik hanya konsentrasi

${ }^{40}$ Al-Farmawi, Metode Tafsir Mawdhu'iy: Suatu Pengantar, terj. Suryan A. Jamrah (Jakarta: Rajawali Pers, 1996), h. 35-36.

${ }^{41}$ M. Quraish Shihab, Wawasan al-Qur'an: Tafsir Maudhu'i atas Pelbagai Persoalan Ummat (Bandung: Mizan, 1996), h. 74. 
pada satu topik tertentu dari al-Qur'an, sedangkan dalam holistik masih diteruskan dengan langkah selanjutnya untuk membangun hubungan yang harmonis antara tiga aspek ajaran Islam; teologis, etika dan hukum.

Karena itu, apa yang ditemukan dengan menggunakan pendekatan tematik barulah satu langkah tertentu dari pendekatan holistik, yang bertujuan untuk menemukan prinsip tertentu pada subjek tertentu tersebut. Sebagai contoh, untuk menemukan prinsip hak dan tanggung jawab antara istri dan suami dalam hidup keluarga, adalah akhir untuk pendekatan tematik, sedangkan untuk pendekatan holistik baru satu langkah, dan harus diikuti dengan langkah berikutnya, yakni menemukan prinsip yang lebih tinggi, yaitu prinsip hubungan antara istri dan suami, dan kemudian dilanjutkan lagi dengan langkah selanjutnya, yaitu untuk menemukan prinsip hubungan antara pria dan wanita, sampai ditemukan prinsip hubungan antara sesama manusia. Akhirnya, ditemukan hubungan yang harmonis antara aturan/hukum/undang, etika, dan teologi.

\section{Perbedaan antara Hukum Umum (Prinsip) dan Hukum Temporal}

Pembedaan antara hukum umum dan hukum temporal oleh Rahman ditemukan dalam berbagai tulisannya. Sebagai contoh, seperti dinyatakan sebelumnya, Rahman menyatakan, "ada kebutuhan mendesak terhadap teori hermeneutik yang akan membantu kita memahami isi al-Qur'an secara keseluruhan, sehingga bagian teologis, etis, dan ethico-hukum al-Qur'an, dapat dibangun menjadi suatu kesatuan yang utuh". ${ }^{42}$ Dalam pernyataan ini, ditemukan istilah etika untuk menunjukkan hukum umum dan istilah ethico-hukum untuk menunjukkan hukum temporal.

Rahman juga menyatakan, "Jika kita melihat al-Qur'an tidak banyak ditemukan hukum umum (prinsip). Sebagian besar isi al-Qur'an memberikan jawaban atau solusi atau keputusan terhadap masalah-masalah konkret. Tetapi, seperti telah saya katakan, solusi terhadap masalah konkret tersebut menyediakan hukum umum sebagai prinsip, baik secara eksplisit maupun implisit". ${ }^{43}$ Kutipan ini menyatakan prinsip umum atau hukum umum (general principle, general law) di satu sisi, dan solusi atau aturan atau hukum temporal (solution, ruling, temporallaw) di sisi lain. Masih ditemukan di beberapa tempat untuk menunjukkan istilah yang sama.

Kaitannya dengan pengelompokan nash tersebut, al-Haddâd membedakan antara (1) Prinsip atau norma universal yang kekal, seperti kredo persatuan, persyaratan etika, keadilan dan kesetaraan, yang berlaku pada semua keadaan dan di semua tempat, dan (2) Hukum temporal yang tergantung pada kontinjensi manusia dan konteks sosial, terutama yang berkaitan dengan kondisi Jahiliyah (pra Islam) periode Arab. ${ }^{44}$ Al-Haddâd menambahkan

${ }^{42}$ Ibid., h. 45.

${ }^{43}$ Rahman, Islam and Moderntiy, h. 20.

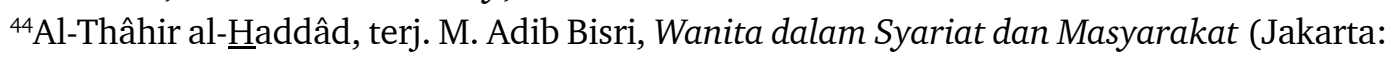


bahwa untuk memahami al-Qur'an lebih baik, adalah dengan memahami konteks historis. Demikian pula, Asghar Ali Engineer membedakan antara normatif dan kontekstual. Sebagaimana dalam tulisannya:

Kita harus memahami bahwa ada normatif serta kontekstual dalam al-Qur'an. Apa keinginan Allah dinyatakan, dan demikian pula apa realitas empiris di dalam masyarakat juga disebutkan. Al-Qur'an sebagai sebuah Kitab Suci menunjukkan tujuan dengan ungkapan 'harus dan/atau seharusnya', tetapi juga mempertimbangkan realitas empiris dengan menyatakan 'keadaannya adalah"'. Kemudian dialektika antara kedua normatif dan kontekstual berlangsung. Sehingga pada saatnya ketika situasi konkret telah kondusif akan ada penerimaan terhadap nilai normatif. Upaya ke arah penerimaan normatif setidaknya selalu diupayakan agar lebih dekat untuk diterima. ${ }^{45}$

Selanjutnya, Ismail Faruqi memberikan nama berbeda untuk menunjukkan substansi sama, yakni: etika dan kasuistik-cosmis; ${ }^{46} \mathrm{John}$ L. Esposito dengan ethico-religius dan sosioekonomi; ${ }^{47}$ Abdul Aziz Sachedina dengan norma tebal dan tipis; ${ }^{48}$ Masdar F. Mas'udi menggunakan istilah ushul fiqih, yakni qath'î dan muhkamat untuk normatif, serta zanni dan juz'îyah untuk hukum temporal (kontekstual). ${ }^{49}$ Karakteristik masing-masing kemudian dijelaskan lebih lanjut oleh Masdar F. Mas'udi: karakteristik nash normatif, bahwa kontennya bersifat universal, prinsip, dasar, dan tidak bergantung pada konteks tertentu; waktu, tempat, situasi, dan semacamnya. Karakteristik nash temporal, di sisi lain, bahwa konten dinyatakan secara rinci, dapat berlaku dan dilaksanakan secara langsung, dan pelaksanaannya tergantung pada konteks: waktu, tempat, situasi dan semacamnya. Boleh juga dikatakan bahwa hukum temporal kental dengan budaya Arab masa Nabi Muhammad SAW. Dengan kata lain, hukum temporal berlaku dalam kehidupan sehari-hari masa Nabi Muhammad SAW.

Abdullah Saeed menetapkan hierarki hukum (nilai) dari al-Qur'an lebih jauh menjadi lima tingkatan, yaitu: (1). Nilai wajib, (2). Nilai fundamental, (3). Nilai protectional, (4). Nilai implementational, dan (5). Nilai pembelajaran. ${ }^{50}$ Adapun aplikasi atau praktik gerakan

Pustaka Pirdaus, 1972), h. 6; Norma Salem, "Islam and the Status of Women in Tunisia", dalam Muslim Women, diedit oleh Freda Hussain, h. 144.

${ }^{45}$ Asghar Ali Engineer, The Rights of Women in Islam (Lahore, Karachi, Islamabad, Peshawar: Vanguard Books (PVT) Ltd., 1992), h. 10-11. Lihat teks hampir sama Asghar Ali Engineer, "Islam The Status of Women and Social Change," dalam Problems of Muslim Women in India, diedit oleh Asghar Ali Engineer (Bombay: Orient Longman Limited, 1995), h. 10.

${ }^{46}$ Isma'il Ragi al-Faruqi, "Towards a New Methodology for Qur'anic Exegesis," Islamic Studies, Vol. 1, No. 1 (March 1962), h. 41.

${ }^{47}$ John L. Esposito, Women in Muslim Family Law (Syracuse: Syracuse University Press, 1982), h. 107.

${ }^{48}$ Abdulaziz Sachedina, 'The Role of Islam in Public Square: Guidance or Governance?. Makalah disampaikan dalam Public lecture in Leiden University by ISIM, Desember, 2003.

${ }^{49}$ Masdar F. Mas'udi, Islam \& Hak-hak Reproduksi Perempuan, Cet. II (Bandung: Mizan, 1997), h. 29-30.

${ }^{50}$ Saeed, Interpreting the Qur'an, h. 132-133. 
pertama dari teori gerakan ganda Rahman (double movements), dari khusus untuk umum, diterapkan pada nash ethico-hukum, hukum temporal, keputusan spesifik, jawaban sederhana yang diberikan al-Qur'an. Tujuan dari generalisasi dimaksud adalah untuk merumuskan hukum umum, prinsip, sasaran, tujuan, nilai (maqâshid).

\section{Signifikansi Pemahaman Konteks dalam Memahami al-Qur'an}

Kunci penting ketiga dari hermeneutika Rahman adalah pentingnya pemahaman konteks historis untuk memahami teks al-Qur'an. Dalam ungkapan Rahman misalnya: "sebenarnya al-Qur'an adalah seperti ujung gunung es, sembilan persepuluh yang terendam di bawah air dan hanya sepersepuluh darinya yang terlihat". ${ }^{51}$ Beberapa kutipan tentang masalah ini telah dikutip di atas dalam kaitannya dengan kritik Rahman terhadap pendekatan lain. Menurut Rahman, untuk memahami makna dan seluruh al-Qur'an adalah dengan cara mempelajari situasi historis dan masalah yang menjadi respons ayat-ayat al-Qur'an. Dengan mengutip Rahman:

Kita harus memahami kepentingan atau makna dari pernyataan yang menjadi respons al-Qur'an, dengan cara mempelajari situasi historis pernyataan atau mempelajari masalah yang menjadi objekjawaban. Tentu saja, mempelajari konteks mikro ini sebelum mempelajari konteks makro (macrosituation), yakni konteks masyarakat, agama, adat, dan lembaga yang hidup di seluruh Arabia, khususnya di sekitar Makkah, tempat turunnya wahyu. ${ }^{52}$

Rahman berpendapat bahwa bagian dari tugas pemahaman pesan al-Qur'an sebagai satu kesatuan adalah mempelajari lengkap dengan latar belakangnya. ${ }^{53}$ Latar belakang yang dimaksud adalah karir dan perjuangan Nabi Muhammad yang berlangsung selama dua puluh tiga tahun di bawah bimbingan al-Qur'an. ${ }^{54}$ Juga relevansi lingkungan Arab dalam hubungan pra Islam dan awal periode Islam, termasuk adat dan sosial, kelembagaan, ekonomi, dan politik, peran penting suku Quraisy dan cara hidup orang Arab. Memahami semua ini, menurut Rahman, adalah suatu usaha untuk memahami pesan al-Qur'an secara keseluruhan. Rahman menyatakan: ${ }^{55}$

Dalam seluruh proses hermeneutika ini harus memperhatikan tujuan ajaran al-Qur'an sebagai keseluruhan, sehingga masing-masing makna yang diberikan dapat dipahami, masing-masing hukum dapat diucapkan, dan masing-masing tujuan dapat dirumuskan, dan akan koheren dengan unsurlain. Al-Qur'an sebagai keseluruhan benar-benarmenanamkan sikap yang pasti terhadap hidup dan benar-benar memiliki weltanschauung konkret,

${ }^{51}$ Ibid., h. 46.

${ }^{52}$ Ibid., h. 6.

${ }^{53}$ Rahman, "Interpreting the Qur'an," h. 45.

${ }^{54}$ Ibid., h. 45.

${ }^{55}$ Ibid., h. 45-46. 
demikian juga dengan demikian dapat menyatakan bahwa ajaran al-Qur'an tidak ada kontradiksi di dalamnya, tetapi koheren secara keseluruhan sebagai satu kesatuan. ${ }^{56}$

Di tempat lain Rahman menjelaskan bahwa proses reformasi yang dilakukan Muhammad terhadap kehidupan sosial dalam al-Qur'an dikembangkan melalui dua prinsip, yaitu: (1) Prinsip berangsur-angsur, dan (2) Prinsip memahami konteks historis. Arti dari reformasi berangsur-angsur, bahwa sebelum memperkenalkan perubahan sosial, lebih dahulu dasarnya dipersiapkan. Sedangkan maksud memahami konteks adalah apa yang lebih populer dengan peristiwa yang menjadi sebab turunnya wahyu (asbâb al-nuzûl dan asbâb al-wurûd). ${ }^{57}$

Pemikir lain yang sama-sama menekankan pentingnya memahami konteks untuk memahami al-Qur'an adalah 'Izzu al-Dîn ibn 'Abd al-Salâm (577-660/1181-1262), dan berpendapat bahwa al-Qur'an diturunkan dalam keadaan sangat beragam dan selama lebih dari dua puluh tahun. Karena itu, dalam kondisi turun seperti ini tidak mungkin kontinuitas dan koherensi (irtibât).

Tahir al- Haddâd adalah sarjana lain yang berpendapat bahwa al-Qur'an diturunkan sebagai respons langsung terhadap masalah-masalah yang muncul di masa Nabi Muhammad SAW. ${ }^{58}$ Karena itu, al-Qur'an lebih dari sebuah buku etika daripada buku undang-undang. Maka solusi yang diberikan muncul dalam bentuk prinsip-prinsip umum. Namun karena ketidakmungkinan untuk melakukannya karena pada saat yang sama al-Qur'an harus relevan dengan masalah perlu ditemukan prinsip umum sebagai norma universal nanti.

Memahami konteks historis al-Qur'an bagi Rahman, pertama untuk menemukan prinsip, rasio logis, objektif, tujuan, dan nilai. Dengan kata lain, dalam hukum tertentu selalu ada ada prinsip, rasio logis, objektif, tujuan, dan nilai. Karena itu, ada dua cara untuk menemukan prinsip menurut Rahman. Pertama, ditemukan dengan memahami konteks dan latar belakang historis dari teks al-Qur'an. Kedua, ditemukan berdasarkan putusan-putusan spesifik dengan melakukan generalisasi. Dalam melakukan generalisasi dari aturan-aturan khusus, harus dipahami sesuai dengan konteks. ${ }^{59}$

Prinsip, rasio logis, objektif, tujuan, dan nilai harus dipertahankan dari waktu ke waktu, dari satu tempat ke tempat lain dan selamanya, yaitu bersifat universal. Konsep dasar prinsip, rasio logis, objektif, tujuan, dan nilai ini sepintas sama dengan 'illat dalam qiyas al-Syâfiî̀, yang terdiri dari tiga unsur, yaitu; hukum asal dinyatakan dalam teks nash (al-Qur'an dan sunnah Nabi Muhammad SAW.), hukum baru sebagai jawaban terhadap masalah kontemporer (furû), dan rasio logis ('illah), sebagai dasar untuk menyamakan hukum antara apa yang disebutkan dalam nash dan terhadap masalah kontemporer.

\footnotetext{
${ }^{56}$ Rahman, Islam and Modernity, h. 6.

${ }^{57}$ Ibid., h. 16-17.

${ }^{58} \mathrm{Al}$ - Haddâd, Wanita dalam Masyarakat, h. 5.

${ }^{59}$ Rahman, "Interpreting the Qur'an," h. 49.
} 
Karena itu, ada kesamaan antara konsep universal Rahman berupa prinsip, rasio logis, objektif, tujuan, dan nilai, dengan 'illah dalam qiyas. Namun, ada perbedaan, dan Rahman mengkritik teori qiyas. Al-Syâfiî̀ menemukan 'illat (alasan di balik hukum) dengan berkonsentrasi pada teks nash (al-Qur'an dan sunnah Nabi Muhammad SAW.), sementara Rahman menemukannya melalui penggalian rasio logis ('illah al- $\underline{h} u k m$ ) dari hukum alQur'an dan mensistematis prinsip-prinsip tersebut secara hierarkis. ${ }^{60}$

\section{Penutup}

Setidaknya ada tiga perbedaan mendasar antara teori Rahman dan teori hermeneutika lainnya. Pertama, Rahman menekankan pemahaman al-Qur'an sebagai satu kesatuan dan keseluruhan. Kedua, Rahman bergantung pada pembedaan antara hukum umum dan hukum temporal (hukum temporal merupakan jawaban terhadap pertanyaan atau masalah yang muncul). Ketiga, Rahman menekankan pentingnya pemahaman konteks untuk memahami al-Qur'an.

Memahami al-Qur'an sebagai satu kesatuan dan keseluruhan berarti bahwa tiga aspek ajaran Islam dihubungkan dan dibangun menjadi satu bangunan yang saling terkait secara koheren dan harmonis. Tiga aspek ajaran Islam dimaksud adalah iman (teologi, pandangan dunia), ihsan (etika), dan Islam (undang-undang, aturan, atau hukum). Dengan kata lain, Rahman berusaha membangun hubungan yang harmonis dan koheren antara ketiga aspek ajaran Islam, lewat generalisasi terhadap hukum temporal untuk membangun hukum umum (prinsip), dengan menggunakan pendekatan tematik, intertekstual). Dari beberapa prinsip dalam satu level kemudian digeneralisir lagi menjadi satu prinsip yang lebih tinggi, dan kemudian lebih lanjut dengan prinsip yang lebih tinggi berikutnya, sampai ditemukan prinsip tertinggi, berupa monoteisme dalam teologi, kesetaraan dan keadilan dalam membangun hubungan antara sesama manusia, dan musyawarah (syûrâ) dalam memutuskan masalah yang dihadapi. Membangun hubungan harmoni dan koheren antara ketiga aspek ajaran Islam adalah tujuan akhir dari teori hermeneutika Rahman. Prinsipprinsip umum kemudian dapat digunakan untuk memecahkan masalah-masalah kontemporer.

Tujuan memahami konteks historis al-Qur'an, bagi Rahman, adalah untuk menemukan prinsip, rasio logis, objektif, tujuan, dan nilai, yang selalu ada dalam dan di belakang hukum temporal. Prinsip, rasio logis, objektif, tujuan, dan nilai ini dicapai dengan memahami latar belakang teks (konteks). Kesimpulan penting lain, bahwa ada hubungan erat antara teori hermeneutik dan pendekatan tematik, terutama dalam kaitannya dengan mencari prinsip umum (generalisasi) dari hukum-hukum temporal dalam suatu subjek tertentu atau dalam tingkat prinsip tertentu. Perbedaannya adalah bahwa dalam tematik lebih terkonsentrasi pada suatu topik tertentu, sedangkan holistik memberikan perhatian lebih untuk membangun hubungan harmonis antara aspek teologis, etika dan hukum.

${ }^{60}$ Ibid., h. 48. 
Selain itu, ada kesamaan antara teori Rahman dan qiyas al-Syâfîî, sama-sama menyetujui adanya substansi hukum pada satu sisi dan hukum temporal pada sisi lain. Substansi hukum ada dari satu tempat ke tempat lain, dan selamanya, sementara hukum temporal hanya berlaku untuk waktu tertentu atau tempat (konteks tertentu). Perbedaannya terletak pada cara menemukannya. Bagi Rahman didapatkan dengan mendialogkan teks dan konteks, sedangkan bagi al-Syâfi'î ditemukan dengan konsentrasi melihat teks, dan melakukan rasionalisasi. Dengan perbedaan ini adalah mungkin untuk menyimpulkan bahwa Rahman berafiliasi dengan realisme, dan al-Syâfi'î dengan idealisme.

\section{Pustaka Acuan}

Berry, Donald L. "Fazlur Rahman: A Life in Review," dalam The Shaping of An American Islamic Discourse, diedit oleh Earle H. Waugh dan Frederick M. Denny. Atlanta and Georgia: Scholars Press, 1998.

Engineer, Asghar Ali. The Rights of Women in Islam. Lahore, Karachi, Islamabad, Peshawar: Vanguard Books (PVT) Ltd., 1992.

Engineer, Asghar Ali. "Islam The Status of Women and Social Change," dalam Problems of Muslim Women in India, diedit oleh Asghar Ali Engineer. Bombay: Orient Longman Limited, 1995.

Esposito, John L. Women in Muslim Family Law. Syracuse: Syracuse University Press, 1982.

Al-Farmawi, Metode Tafsir Mawdhu'iy: Suatu Pengantar, terj. Suryan A. Jamrah. Jakarta: Rajawali Pers, 1996.

Al-Faruqi, Isma'il Raji . “Towards a New Methodology for Qur'anic Exegesis,” dalam Islamic Studies, Vol. 1, No. 1. Maret, 1962.

Al- Haddâd, al-Thâhir. Wanita dalam Masyarakat, terj. M. Adib Bisri. Jakarta: Pustaka Pirdaus, 1972.

Ibn Taimîyah, Taqi al-Dîn. Muqaddimah fî Ushûl al-Tafsîr. Beirût: Dâr Ibn $\underline{\text { Hazm, }} 1994$.

Al-Khûlî, Amîn. Manâhij Tajdîd fî al-Nahw wa al-Balâghah wa al-Tafsîr wa al-Adab. t.tp.: AlHai'ah al-Mishriyah al-'Âmmah li al-Kitâb, 1995.

Mas'udi, Masdar F. Islam dan Hak-Hak Reproduksi Perempuan, Cet. 2. Bandung: Mizan, 1997.

Rahman, Fazlur. "Interpreting the Qur'an,” dalam Afkar/Inquiry, May 1986.

Rahman, Fazlur. "Islam: Challenges and Opportunities", Islam: Past Influence and Present Challenge, diedit oleh Alford T. Welch dan Pierre Cachia. Edinburgh: Edinburgh University Press, 1979.

Rahman, Fazlur. "Islamic Modernism: Its Scope, Method and Alternatives," dalam International Journal of Middle Eastern Studies, Vol. I. 1970.

Rahman, Fazlur. “The Concept of Hadd in Islamic Law," Islamic Studies, Vol. IV 1965.

Rahman, Fazlur. "Toward Reformulating the Methodology of Islamic Law: Sheikh Yamani on 'Public Interest' in Islamic Law,” International Law and Politics, Vol. XII. 1979. 
Rahman, Fazlur. Islam and Modernity: Transformation of an Intellectual Tradition. Chicago \& London: The University of Chicago Press, 1982.

Rahman, Fazlur. Major Themes of the Qur'an. Chicago: Bibliothca Islamica, 1980.

Rahman, Fazlur. "Some Key Ethical Concepts of the Qur'an," dalam Journal of Religious Ethics, Vol. XI, No. 2, 1983.

Rahman, Fazlur. "The Qur'anic Concept of God, the Universe and Man," Islamic Studies, Vol. VI, No. 1 (1967), h. 1-19.

"Review Essay" dalam Approaches to Islam in Religious Studies, diedit oleh Richard C. Martin Tucson: The University of Arizona Press, 1985).

"Review Essay", dalam Islam and Modernity: Transformation of an Intellectual Tradition. Chicago: The University of Chicago Press, 1982.

Sachedina, Abdulaziz. "The Role of Islam in Public Square: Guidance or Governance?” Makalah disampaikan dalam Public lecture in Leiden University by ISIM, Desember, 2003.

Saeed, Abdullaah. Interpreting the Qur'an: Towards a Contemporary Approach. London \& New York: Routledge, 2006.

Salem, Norma. "Islam and the Status of Women in Tunisia", dalam Muslim Women, diedit oleh Freda Hussain.

Al-Syâthibî, Ibrâhîm ibn Mûsâ. al-Muwâfaqât, ed. Muhammad Muhy al-Dîn 'Abd al-Hââmid. Kairo: Maktabat wa Mathba'at Muhammad 'Alî Shâbih wa Awlâdih, 1969.

Al-Shâthi', Binti. al-Qur'ân wa Tafsîr 'Ashr. Kairo: Dâr al-Ma'ârif, 1970.

Shihab, M. Quraish. Wawasan al-Quran: Tafsir Maudhu'i atas Pelbagai Persoalan Ummat. Bandung: Mizan, 1996.

Sonn, Tamara. "Fazlur Rahman" dalam John L. Esposito (ed.). The Oxford Encyclopedia of the Modern Islamic World. New York, Oxford: Oxford University Press, 1995.

Sonn, Tamara. "Fazlur Rahman's Islamic Methodology," dalam Muslim World, No. 81, No. 3-4, July-October, 1991.

Syamsuddin, Sahiron. "An Examination of Bint Bint al-Syâthi's Method of Interpreting the Qur'an”. Thesis, Montreal: McGill University, 1998.

Al-Zarkashî, Muhammad ibn 'Abdillâh. al-Burhânfí 'Ulûm al-Qur'ân, diedit oleh Muhammad Abû al-Fadhl Ibrâhîm. Kairo: Dâr Ihyâ’ al-Kutub al-'Arabîya, 1957. 